\title{
PAX3/F0X01 Fusion Protein
}

National Cancer Institute

\section{Source}

National Cancer Institute. PAX3/FOXO1 Fusion Protein. NCI Thesaurus. Code C53623.

A fusion protein (836 aa, 92 kDa) encoded by the PAX3/FOXO1 fusion gene. This protein is comprised of the N-terminal DNA binding domain of paired box protein Pax-3 and the C-terminal transactivation domain of forkhead box protein 01. 